\title{
Allogeneic BMT in ATL: whom to transplant and which modality to use
}

\author{
Mari Kannagi \\ From 16th International Conference on Human Retroviruses: HTLV and Related Viruses \\ Montreal, Canada. 26-30 June 2013
}

\begin{abstract}
Allogeneic hematopoietic stem cell transplantation (HSCT) has been used for treatment of ATL in Japan since 90's, mainly for the patients with acute or lymphoma types of ATL after chemotherapies. The 3-year overall survival of HSCT in ATL is $31-39 \%$, and many of the survivals live without disease for a long time. However, the treatment-related mortality (TRM) of HSCT is also high. Graft-versus-host (GVH) response is likely involved in both anti-tumor effects and TRM. Immunological study indicates the potential involvement of Tax-specific CTL in long-lasting anti-tumor surveillance after HSCT as well, suggesting that a tumor-vaccine to activate these CTL might partly reproduce the long-lasting effects of HSCT and could be an alternative choice of therapy following other initial therapies. The clinical trial of immunotherapy with Tax-peptide pulsed dendritic cells, currently undergoing in collaboration of National Kyushu Cancer Center, Kyushu University, and Tokyo Medical and Dental University, will find the answer.
\end{abstract}

Published: 7 January 2014

Submit your next manuscript to BioMed Central and take full advantage of:

- Convenient online submission

- Thorough peer review

- No space constraints or color figure charges

- Immediate publication on acceptance

- Inclusion in PubMed, CAS, Scopus and Google Scholar

- Research which is freely available for redistribution

(c) 2014 Kannagi; licensee BioMed Central Ltd. This is an Open Access article distributed under the terms of the Creative Commons 